\title{
Local genetic structure within two rookeries of Chelonia mydas (the green turtle)
}

\author{
TIGERIN PEARE* \& PATRICIA G. PARKER \\ Department of Zoology, Ohio State University, Columbus, OH 43210, U.S.A.
}

\begin{abstract}
We used multilocus minisatellite DNA fingerprinting to examine the local genetic structure within nesting populations of green turtles (Chelonia mydas) in Tortuguero, Costa Rica and Melbourne, Florida, USA. In the Tortuguero population, there was a significant negative correlation between genetic similarity of pairs of nesting females and the distance between their nest sites both within years $\left(r^{2}=0.273 ; P<0.001\right)$ and between years $\left(r^{2}=0.578\right.$; $P<0.001)$. Of the 122 female pairs scored for Tortuguero, 12.3 per cent had genetic similarity values resembling those of mother-offspring pairs. In the Melbourne population, however, no relationship between genetic similarity and distance was found $\left(r^{2}=0.017 ; P=0.075\right)$. The distance-related genetic structure of the Tortuguero population indicates that these females exhibit low levels of dispersal from natal sites, and that nestmates return independently to nest near their natal sites. The lack of a similar structure in the Melbourne population suggests that females from this population may not return to natal sites with comparable precision. High levels of mortality among nests, hatchlings or maturing turtles produced in the Melbourne rookery may also be responsible for the absence of distance-related local genetic structure.
\end{abstract}

Keywords: Chelonia mydas, DNA fingerprinting, genetic structure, philopatry.

\section{Introduction}

Genetic differentiation can occur within a continuous population if the effective dispersal rate of individuals is restricted (Wright, 1943a). Significant departure from randomly distributed genotypes over a continuous area may occur as a result of spatially distinct selective pressures within an environmentally heterogeneous habitat, or may result from low rates of dispersal by members of the population occupying the range (Ehrlich \& Raven, 1969; Rohlf \& Schnell, 1971; Sokal \& Wartenberg, 1983). There are several examples of within-population genetic divergence associated with discrete variations in habitat. For example, genetic subdivision occurs in plant populations where sections of the soil contain heavy metal wastes from mining activities (Jain \& Bradshaw, 1966; Antonovics \& Bradshaw, 1970). Genetic changes conferring resistance to the rodenticide, warfarin, have been found in treated rats whereas adjacent, untreated individuals (separated by distances as small as $5 \mathrm{~m}$ ) show no changes (Bishop \& Hartley, 1976; Bishop et al., 1977; Bishop, 1981).

${ }^{*}$ Correspondence.

(C)1996 The Genetical Society of Great Britain.
Spatially distinct selective pressures have also been implicated as the cause of genetic subdivision within several other species including populations of Daphnia (Weider, 1985), Anthoxanthum plants (Snaydon \& Davies, 1972), and Borrichia plants (Antlfinger, 1981).

In the absence of discrete differences in selection within a habitat, genetic divergence has been attributed to the short-range dispersal of pollen or propagules. Selander (1970) reported genetic subdivision within a population of mice inhabiting a barn and concluded that limited movement and mating between mice from different areas within the barn was responsible for this divergence. Similar dispersal-related, local genetic structure has also been observed within populations of several taxa including mammals (e.g. White \& Svendsen, 1992), birds (e.g. Barrowclough \& Coats, 1985), fish (e.g. Chapman, 1989) and plants (e.g. Wright, 1943b).

For organisms with short-distance dispersal from natal sites, the shape of the area occupied by a population can have a strong effect on its genetic structure (Wright, 1943b). When organisms occupying a circular range have dispersal distances that are large relative to the diameter of the habitat, complete mixture of alleles is possible during each 
generation. The same dispersal distance in an elongated range of equal area will not spread alleles as effectively; local structure can result (Wright 1943a, 1951; Rohlf \& Schnell, 1971). Green turtles (Chelonia mydas) lay their clutches on virtually linear ocean beaches which can be many kilometres in length but only several metres wide. Nesting populations consist of adult females that have migrated hundreds or thousands of kilometres from feeding grounds to converge on particular beaches where they lay their eggs. If females exhibit precise homing to specific natal sites along a rookery, genetic structure may develop through isolation by distance. Like all species of marine turtles, life history parameters of green turtles make the direct study of effective dispersal very difficult. An estimated 27-33 years are required for females in the Atlantic to reach sexual maturity (Frazer \& Ladner, 1986), and individuals move widely among different marine habitats during their development (Carr, 1980). These features make it virtually impossible to track individuals from the hatchling stage to the first nesting event in order to observe the realized dispersal distances from natal sites. Indirect methods have therefore been used to examine dispersal in this species.

Meylan et al. (1990), Bowen et al. (1992) and Allard et al. (1994), using maternally-transmitted mitochondrial DNA, found significant divergence among different nesting populations of green turtles. They concluded that females exhibit strong homing behaviour to natal rookeries and hence contribute very little to the exchange of any genetic material between populations. Data from tag returns have revealed that female green turtles tend to return to specific sections of a rookery to nest (Carr \& Hirth, 1962; Carr \& Carr, 1972; Mortimer \& Portier, 1989; Johnson, 1994). These results provide evidence that females show homing precision to areas of the beach where they have previously nested.

Although these studies have revealed that females tend to return to natal beaches, and to sites they have used before, it is unknown whether the first nesting site is also near the natal site. If female turtles are returning to nest at natal sites, genetic structure can develop which may be identified through the use of high-resolution genetic techniques. Multilocus minisatellite DNA fingerprinting (Jeffreys et al., 1985) provides a way to assess relatedness among individuals by producing individualspecific banding patterns (genotypes). This technique is commonly used in paternity analysis (e.g. Burke \& Bruford, 1987; Rabenold et al., 1990; Decker et al., 1993); however, it has more recently been used for population-level analyses (e.g. Gilbert et al., 1990; Triggs et al., 1992; Parker \& Whiteman, 1993). The ability to use DNA fingerprinting to produce individual-specific banding patterns of nesting green turtles provides a way to determine the spatial distribution of genotypes within a rookery.

We used multilocus minisatellite DNA fingerprinting to examine the local genetic structure along two nesting populations (Tortuguero, Costa Rica and Melbourne, FL, USA) to assess the extent to which female green turtles exhibit within-beach precision in natal philopatry. If females return to their natal site to nest, then individuals that nest in a particular section of beach should be more closely related than individuals that nest several kilometres apart. Because spatial clumping of related individuals within a nesting season would also be expected if female kin groups nest together on randomly selected sections of the beach, we compared the relationship between distance and genetic similarity for pairs of females nesting 1 or 2 years apart in the Tortuguero population. If individuals returned to their natal site to nest, then two turtles from two different years that nest in a particular section of beach should be closely related. If, on the other hand, females show no natal philopatry, but nest near their kin, then turtles from different years that nest in the same area should not be closely related. To calibrate the relatedness among females nesting along Tortuguero beach, we compared the genetic similarity values of first-order relatives (motheroffspring pairs) with the scores of adult females.

Distance-related genetic structure along nesting beaches would indicate that populations are composed of several genetic neighbourhoods or spatially discrete lineages. For populations of conservation concern, like those of endangered green turtles, such an organization may have serious genetic consequences if disturbances are also spatially discrete; particular lineages may be disproportionately impacted, causing the population to lose genetic diversity.

\section{Materials and methods}

\section{Field methods}

During the summers of 1991 to 1993, a total of 98 blood samples $(20-100 \mu \mathrm{L})$ were collected from adult female green turtles nesting on the northernmost $8 \mathrm{~km}$ of Tortuguero Beach, Costa Rica. Blood was taken by intravenous sampling from either the dorsal cervical sinus using 18 gauge needles or the femoral vein using 23 gauge needles. Clutches laid 
by these individuals were marked and monitored throughout the summer. Blood samples were collected from a total of 430 hatchlings (represent. ing ten clutches) as they emerged from monitored nests of sampled females. Incubation periods ranged from 56 to 78 days. Emerging hatchlings were placed in buckets lined with moist sand and covered with dark towels. Blood collection took place at shelters away from the beach to decrease the risk of overheating for hatchlings that emerged in the early morning, and to eliminate the need for headlamps on the beach when hatchlings emerged at night. Forty $-\mu \mathrm{L}$ heparinized capillary tubes were used to collect $10-30 \mu \mathrm{L}$ blood from hatchlings after venipuncture of the dorsal cervical sinus using 26 gauge needles. Following blood collection, hatchlings were returned to their specific nest sites and allowed to crawl down to the surf. Blood samples $(50-100 \mu \mathrm{L})$ from the femoral vein were also collected in 1994 from 50 adult female green turtles nesting on $16 \mathrm{~km}$ of Melbourne Beach, FL, USA, between Sebastian Inlet and Coconut Point Park. Each blood sample (from both populations) was stored in $1 \mathrm{~mL}$ of a lysis buffer (100 mM Tris, $\mathrm{pH} 8,100 \mathrm{~mm}$ EDTA, 10 $\mathrm{mm} \mathrm{NaCl}, 0.5$ per cent SDS; Longmire et al., 1988). Tortuguero Beach is marked with stakes every 0.2 $\mathrm{km}$ and Melbourne Beach every $0.1 \mathrm{~km}$ so the location of each nesting turtle was recorded based on its proximity to the nearest beach marker.

\section{Laboratory methods}

Samples were incubated overnight at $65^{\circ} \mathrm{C}$ with 25 $\mu \mathrm{L}$ proteinase $\mathrm{K}\left(10 \mathrm{mg} \mathrm{mL}^{-1}\right)$. DNA was extracted from samples by two phenol extractions, two phenol:CIA (chloroform:isoamyl alcohol at 24:1) extractions and one CIA extraction. Samples were dialyzed for $3-10 \mathrm{~h}$ in cold $\mathrm{TNE}_{2}$ (10 mM Tris, $10 \mathrm{~mm} \mathrm{NaCl}$, 2 mM EDTA, pH 8.0). For each individual, $4 \mu \mathrm{g}$ DNA was digested with $5 \times$ excess $\mathrm{HaeIII}$ at $37^{\circ} \mathrm{C}$ for $3-5 \mathrm{~h}$. The fragments produced by digestions were separated by size along an electrical gradient in a 0.8 per cent agarose gel for $65 \mathrm{~h}$ at $20 \mathrm{~V}$. Southern blotting (Southern, 1975) was used to transfer the DNA to a nylon membrane, to which it was fixed by UV cross-linking. Membranes were hybridized with Jeffreys's probe 33.15 (Jeffreys et al., 1985), which had been labelled by primer extension with $\alpha \mathrm{T}^{32} \mathrm{PdCTP}$. Hybridizations were run overnight at $62^{\circ} \mathrm{C}$ in $1.5 \times$ SSC, 0.1 per cent SDS, $5 \times$ Denhardt's solution and 6 per cent w:v dextran sulphate. Following hybridization, filters were washed four times at $62^{\circ} \mathrm{C}$ in $1.5 \times$ SSC and 0.1 per cent SDS, then exposed to $\mathrm{X}$-ray film at $-20^{\circ} \mathrm{C}$ for $\geq 24 \mathrm{~h}$ with intensifying screens.

Randomly selected DNA samples from Tortuguero and Melbourne Beach adult green turtles were run on four gels. Three additional gels were run that represented three partial families (female turtles and between 10 and 17 of their hatchlings). As the distance between two lanes increases the accuracy of band-sharing estimates decreases (Piper \& Parker Rabenold, 1992). To address this problem, the following approach was used: DNA from one to two individuals was repeated two to three times within each gel. On the autoradiograms, horizontal lines were drawn connecting five or six of the identical bands in the repeated lanes. The autoradiograms were then sliced apart between each lane, and the horizontal lines were used to position the strips so that the five to ten closest lanes could be scored adjacent to one another. This method could be used on gels that had run straight, so that all horizontal lines could be connected.

\section{Data analysis: relationship between internest distance and genetic similarity}

Genetic similarity values (proportion of bands shared) were calculated for dyads of nesting females as $D=2 S /(2 S+A+B)$, where $S$ equals the number of bands shared by the two individuals under comparison, $A$ is the number of bands exclusive to one, and $B$ is the number exclusive to the other (Lynch, 1990). The local genetic structure within each population was determined by examining the genetic similarity of female pairs as a function of the distance between their nest sites. For the Tortuguero population we examined this relationship for turtles nesting in the same year $(1991 ; n=14)$ and for those nesting in different years (1991, $n=6$; $1992, n=5 ; 1993, n=7)$. For the Melbourne population, turtles nesting in $1994(n=19)$ were analysed.

Because of the lack of independence of the data points (each female was scored against multiple other individuals) the Mantel test (Mantel, 1967) was used to evaluate whether genetic similarity values and distance were correlated for pairs of turtles nesting in Tortuguero and in Melbourne. We used two symmetrical similarity matrices for each test (one for genetic similarity based on bandsharing values and a corresponding matrix of distances between nest sites), and then assessed the significance of the relationship between the elements of the two matrices through permutational analysis (Schnell et al., 1985). This analysis randomly 
permutes the order of the elements of one matrix, while holding the other constant, and compares the correlation values for each of a specified number (we used 1000) of permutations to the initial correlation using the original matrix. The computer program Numerical Taxonomy and Multivariate Analysis System (NTSYS-pc) was used for both the Mantel matrix correlation test and the permutational analysis (Rohlf, 1990).

\section{Data analysis: calibrating relatedness among females}

To evaluate the genetic relatedness of nesting females for the Tortuguero population, band-sharing scores were calculated for mother-offspring pairs to generate a distribution of genetic similarity values for first-order relatives. This distribution was then used to examine whether any pairs of nesting females consisted of close genetic relatives. We calculated the 95 per cent confidence interval (mean $\pm 1.96 \times \mathrm{SD}$ ) for the distribution of motheroffspring pairs and for the distribution of all female pairs. This allowed us to determine if any of the female-female pairs fell into the distribution for first-order relatives, and therefore represented closely related individuals.

Using the values for first-order relatives calculated from the mother-offspring pairs, we estimated the expected mean genetic similarity value for unrelated individuals (Georges et al., 1988). We then compared this expected mean with the mean calculated for all female pairs. A higher than expected value for mean genetic similarity would provide evidence that some pairs consisted of related females. Where a relationship existed between genetic similarity and internest distance, we defined potentially unrelated pairs as those with internest distances greater than a particular threshold value. The threshold value was determined by identifying the point in the relationship between internest distance and genetic similarity above which high genetic similarity values no longer occurred.

\section{Results}

\section{Relationship between internest distance and genetic similarity}

In the Costa Rica population, there was a significant negative correlation (Mantel matrix correlation $\left.r^{2}=0.273 ; P<0.001\right)$ between genetic similarity and internest distance (Fig. 1). Thus individuals nesting

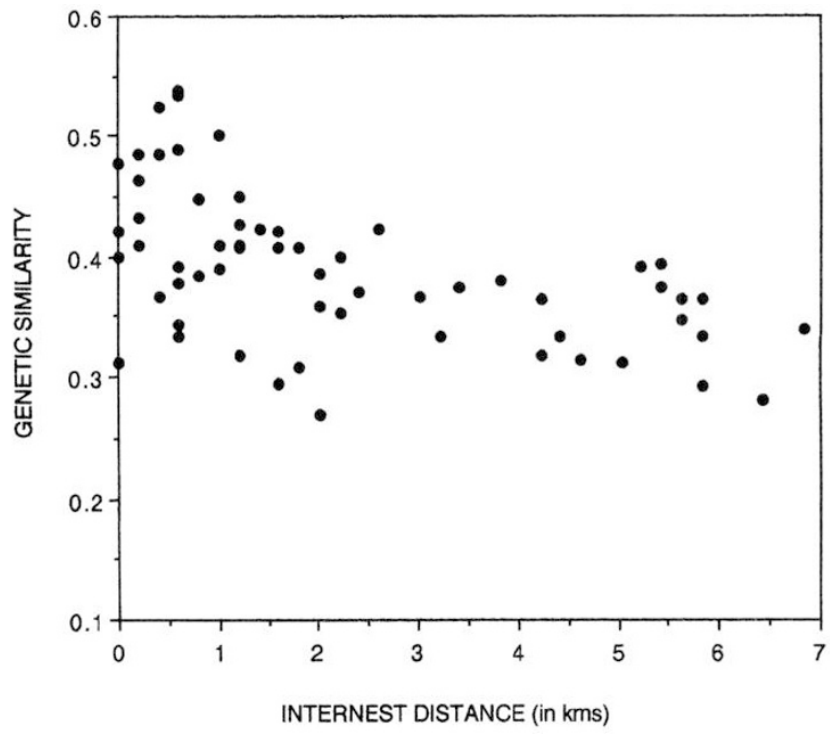

Fig. 1 Relationship between internest distance and relatedness for 60 pairwise comparisons of 14 green turtles nesting along Tortuguero Beach in 1991. Internest distance and genetic similarity values show a significant negative correlation (Mantel matrix correlation $r^{2}=0.273$; $P \leq 0.001)$.

in the same area are more likely to be close relatives than those nesting farther apart. This indicates that there is little movement of alleles along the length of the beach, and suggests that females are returning to natal sites within beaches to nest.

The relationship between genetic similarity and internest distance is stronger for pairs of females that nested 1 or 2 years apart in Tortuguero (Mantel matrix correlation $\left.r^{2}=0.578 ; \quad P<0.001\right)$. Even between years, pairs of turtles nesting in the same parts of the beach have higher genetic similarity values than pairs nesting in different parts of the beach (Fig. 2). In contrast, the Melbourne population shows no relationship between genetic similarity and internest distance for pairs of nesting females (Fig. 3; Mantel matrix correlation $r^{2}=0.017$; $P=0.075)$. The lack of distance-related genetic structure within Melbourne fails to reveal precise natal philopatry by the females of this population.

\section{Calibrating relatedness among nesting females}

Figure 4 shows the distribution of genetic similarity values for mother-offspring pairs and for all adult female pairs. The 95 per cent confidence interval for female pairs is $0.252-0.553$. The upper end of the distribution for female pairs overlaps with the distribution for first-order relatives (95 per cent 


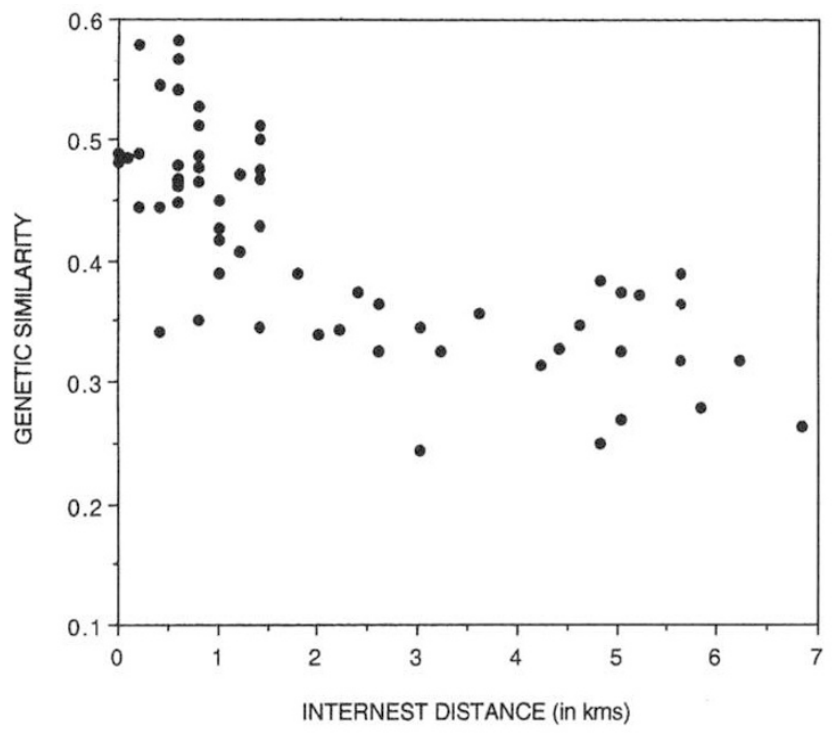

Fig. 2 Relationship between internest distance and relatedness for 62 pairwise comparisons of 18 green turtles nesting along Tortuguero Beach between 1991 and 1993; 25 pairs nested two years apart and 37 pairs nested one year apart. Internest distance and genetic similarity values show a significant negative correlation (Mantel matrix correlation $r^{2}=0.578 ; P \leq 0.001$ ).

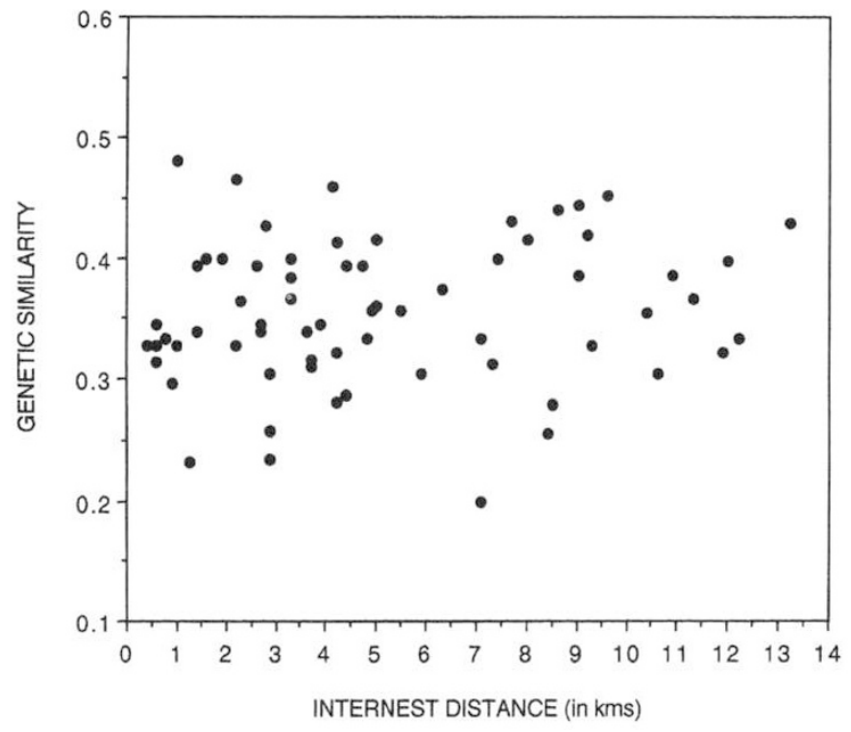

Fig. 3 Relationship between internest distance and relatedness for 66 pairwise comparisons of 19 green turtles nesting along Melbourne Beach in 1994. Internest distance and genetic similarity values were not significantly correlated (Mantel matrix correlation $r^{2}=0.017$; $P=0.075$ ).

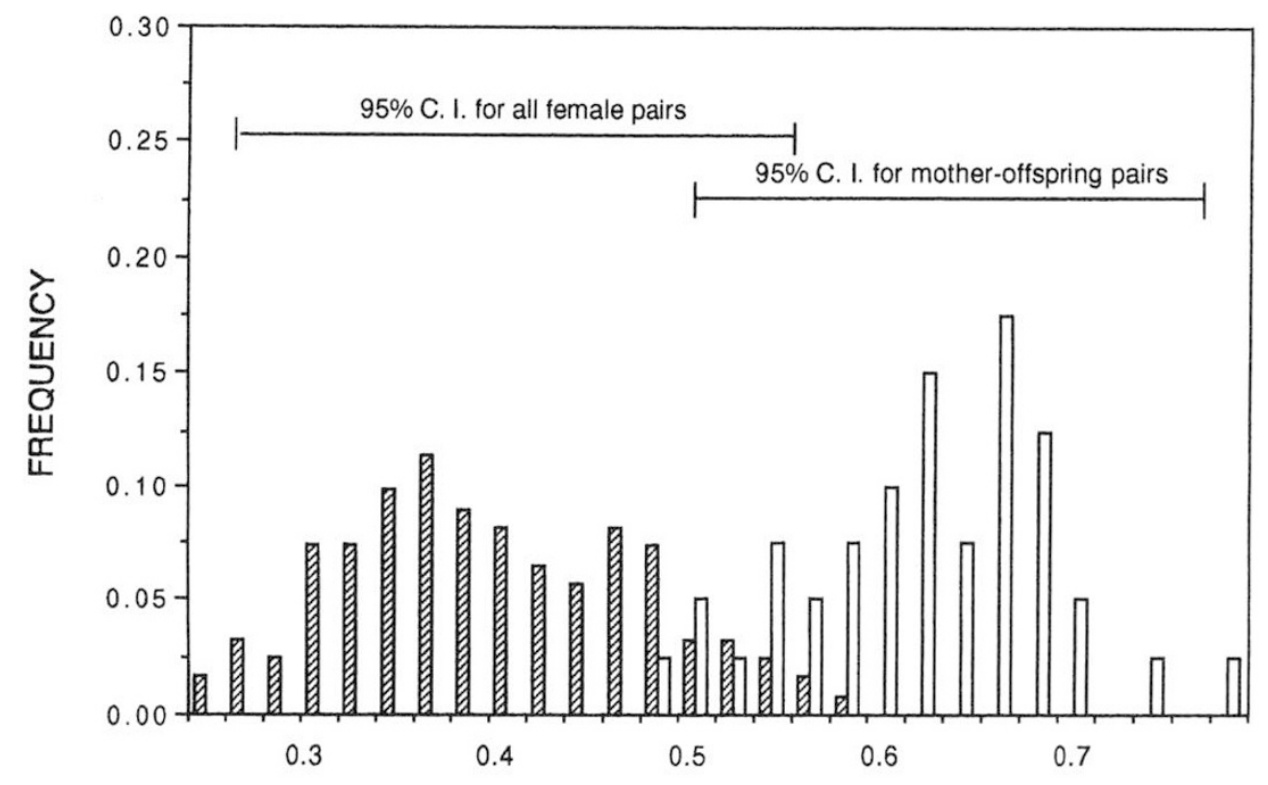

שemale pairs

GENETIC SIMILARITY

mother-offspring pairs

Fig. 4 Distributions of genetic similarity scores for 41 mother-offspring pairs and for all 122 female pairs $(n=26)$ of green turtles nesting along Tortuguero Beach. The bars above each distribution identify the 95 per cent confidence intervals (for mother-offspring pairs, 0.496-0.765; for all female pairs, 0.252-0.553).

(C) The Genetical Society of Great Britain, Heredity, 77, 619-628. 


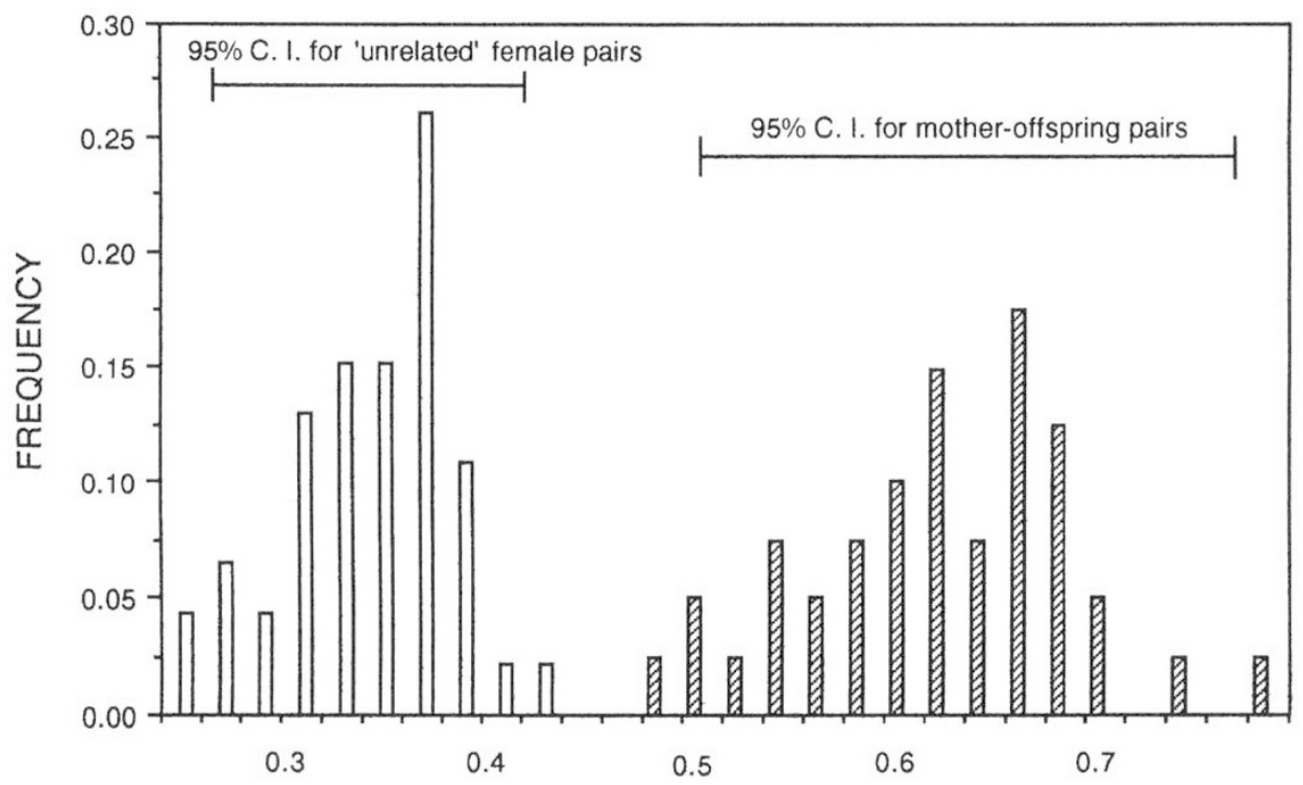

GENETIC SIMILARITY

mother-offspring pairs

'unrelated' females

Fig. 5 Distributions of genetic similarity scores for 41 mother-offspring pairs and for 46 female pairs $(n=26)$ of green turtles nesting more than $2 \mathrm{~km}$ apart (identified as 'unrelated' pairs). The bars above each distribution identify the 95 per cent confidence intervals (for mother-offspring pairs, 0.496-0.765; for 'unrelated' females, 0.261-0.423).

$\mathrm{CI}=0.496-0.765$ ) where 12.3 per cent (15 of 122) of the scores for all female pairs are higher than the lower 95 per cent confidence limit of the distribution for first-order relatives (0.496). In addition, none of these 15 pairs (with scores over 0.496 ) had internest distances higher than $1.407 \mathrm{~km}$ (mean distance 0.737 $\mathrm{km}, \mathrm{SD}=0.370$ ). These results indicate that several of the pairs of females scored for this analysis are composed of closely related individuals.

Based on the band-sharing scores from the distribution of first-order relatives, we calculated the expected mean genetic similarity value for unrelated pairs (Georges et al., 1988). This value, 0.327, is lower than the mean score for female pairs (mean $=0.402 ; \mathrm{SD}=0.077$ ), indicating that the mean for randomly selected pairs of nesting females is inflated by the presence of closely related individuals nesting near each other. To explore this possibility, we categorized each pair of females as 'near' or 'far' based on the distance apart that members of the pair nested. The cutoff point used to distinguish 'near' from 'far' was identified as the point in the relationship beyond which the $r^{2}$ value fell below 0.1 (at $2 \mathrm{~km}, r^{2}=0.098$ ). After eliminating all female pairs that had internest distances less than $2 \mathrm{~km}$, we calculated the mean genetic similarity value of the remaining, more distant pairs. These 'unrelated' pairs had a mean score of $0.342(\mathrm{SD}=0.041)$ which is close to the expected value for unrelated individuals, and is significantly lower than the mean for all female pairs (Mantel $T=-10.321 ; P<0.001$ ). In addition, the 95 per cent confidence interval for the distribution of female pairs nesting far apart (0.261-0.423) does not overlap with the distribution for first-order relatives (Fig. 5). These analyses provide evidence that some of the pairs in the distribution of female-female genetic similarity scores represent closely related individuals and that these individuals tend to nest near one another.

\section{Discussion}

The results of this study reveal a distance-related genetic structure in the Tortuguero population (Fig.1) which persists (and actually strengthens) when comparing different individuals from separate nesting seasons (Fig. 2). Females migrate to the nesting beach every 2-3 years (Carr et al., 1978); therefore, if related females nest independently rather than synchronously, the probability of detect- 
ing these pairs is lower within a single year than among three different seasons. This higher probability of detecting related pairs over multiple seasons may account for the apparent difference in the $r^{2}$ values observed for the two correlations (Figs 1 and 2). The upper end of the distribution of genetic similarity values for all females overlaps with the distribution for first-order relatives (Fig. 4). The mean genetic similarity value for pairs of females nesting more than $2 \mathrm{~km}$ apart is significantly lower than the mean for all female pairs (Fig. 5). Together, these results indicate that turtles are returning to their natal sites to nest, but it does not rule out the possibility that they may also be returning in kin groups.

The population of green turtles nesting at Melbourne Beach showed no distance-related genetic structure (Fig. 3). These results suggest that Melbourne turtles may not exhibit the same level of precision in natal homing as the Tortuguero turtles and, as a consequence, sufficient gene flow is occurring along the beach to mix alleles within this population. Although these results reveal that green turtles in Tortuguero typically exhibit short-distance dispersal from natal sites, the factors affecting the occurrence of local genetic structure in the Melbourne rookery are unknown. The difference may be a result of differential precision in homing, or of demographic parameters affecting each rookery.

Although female green turtles from both the Costa Rica and Florida rookeries exhibit strong philopatry to natal beaches (Allard et al., 1994), the level of within-beach homing precision may differ between the two nesting populations. A difference in natal philopatry between the two populations may be caused by the level of human disturbance that each experiences. The Melbourne population is exposed to high levels of potential disturbance in the form of artificial lighting (Witherington, 1992) associated with beach development. However, there is much less development along Tortuguero Beach, so disturbance to nesting turtles in this population is likely to be lower. If Florida turtles are forced to move farther along the beach to nest, the average natal dispersal distance will be elevated and any natural genetic structure may be disrupted.

Tag return data from green turtles nesting along Melbourne Beach show that these females exhibit site fidelity within and between nesting seasons (Johnson, 1994). These data suggest that Melbourne turtles are capable of distinguishing among different sections of the beach; however, whether they are distinguishing natal sites from other sites is unknown. It is possible that many first-time nesters abort attempts to return to their natal site because of disturbance from human development and, instead, nest in less developed areas that may be some distance away. If disturbance there remains low, females may remain faithful to this section of beach and return for subsequent nesting events, thereby exhibiting fidelity to their first nesting site.

A second possible reason for a difference in natal philopatry between the two populations is that the turtles from Tortuguero may be able to home with greater precision because better cues are available to them. Migrating females may use magnetic fields (Lohmann, 1992) or olfactory cues (Carr, 1967; Koch et al., 1969) to orient and return to natal beaches. It is possible that Tortuguero Beach may provide high quality magnetic or olfactory information that allows turtles to distinguish among different sections of the nesting beach even after long absences. If cues of comparable quality are unavailable on Florida beaches, turtles nesting there would show greater natal dispersal.

Tag return information of Melbourne turtles indicates that adult females nest near their previous nesting sites (Johnson, 1994). However, the cues used by females to return to a specific nesting area may be ephemeral, changing in strength or location over the course of only a few years. Females may be capable of returning to a previous nesting site based on these cues, but then, during each nesting event, they may gather current information for homing in subsequent seasons. The estimated time to reach sexual maturity for green turtles in the Atlantic is between 27 and 33 years (Frazer \& Ladner, 1986). Once they have reached breeding age, females return to the rookery every 2 to 3 years to nest (Carr \& Ogren, 1960). If olfactory, visual or magnetic cues along Florida's coast change more rapidly than those along Costa Rica's Atlantic coast, a first-time nester from Melbourne may not be capable of identifying her natal site, but a re-nester may recognize her previous nesting area. In contrast, a first-time nester returning to Tortuguero may find reliable cues that allow her to distinguish her natal site from other parts of the rookery.

Strong natal philopatry in the Tortuguero population has produced genetic structure where different lineages of turtles are represented in different sections of the beach. The effects of disrupting such a system are unknown. However, costs associated with forced dispersal from natal sites may result in lower fitness for dispersing individuals. For example, green turtles are herbivorous and are generally unable to find sufficient food along the nesting 
beach (Carr, 1982); they rely instead on stored fat as the source of energy for reproduction and activity during the nesting season (Bjorndal, 1982). A considerable amount of energy may be expended in repeated attempts to nest. For this reason, continued disturbance to turtles could result in depleted energy reserves not only from multiple failed nesting attempts, but also from searching for a new, suitable section of beach. Energy diverted from reproduction to nest site selection can reduce fitness of affected turtles and ultimately decrease the net productivity of an already declining population.

Decreases in the number of nesting females in a particular area have been observed following beach development (Worth \& Smith, 1976; Mortimer, 1982). There is evidence that artificial lighting associated with such development is a major factor influencing the reduction of nesting activity (Witherington, 1992). If female green turtles have been sufficiently disturbed by development and photopollution along Florida's coast, this may have resulted in increased natal dispersal distances and subjected individuals to the fitness costs of greater dispersal.

If, on the other hand, dispersal from natal sites is characteristic of females nesting in Florida, and this dispersal is the result of natural factors such as the quality of stable environmental cues, then the differences in the genetic structure between the two populations may simply reflect differences in breeding ecology. In a situation such as this, where individuals from one population exhibit strong natal site fidelity, and individuals from another tend to disperse farther, the population with dispersing individuals is likely to be less susceptible to any detrimental genetic consequences associated with spatially discrete disturbances. This is because the loss of genetic diversity (resulting from the disproportionate reduction in fitness of particular lineages that are forced to disperse from disturbed sites) is reduced if lineages are not concentrated in spatially discrete sections of the beach.

Alternatively, local genetic structure within each rookery may be influenced not by differences in within-beach homing precision, but rather by different levels of nest or hatchling mortality (B. Bowen, personal communication). The probability of detecting distance-related genetic structure within a rookery is enhanced when more relatives survive. Therefore, if hatchlings from Tortuguero enjoy higher survivorship to sexual maturity, and exhibit natal philopatry, there would be more relatives within a cohort nesting in the same section of beach. Lower levels of survivorship among nests and hatch- lings within Melbourne could ultimately produce a nesting population with few close relatives, making local genetic structure more difficult to detect. The annual nesting population of green turtles at Tortuguero ranges between about 6000 to 23000 females (Carr et al., 1978) whereas the Melbourne population numbers only about 30 to 700 females per year (Johnson, 1994). Higher levels of mortality among turtles produced at Melbourne may be associated with this rookery's small size. Population comparisons of mortality rates of different life stages could be used to evaluate this possibility. Alternatively, genetic studies could be performed to compare directly the frequency of close relatives among adult females.

Examining the genetic structure within other populations could prove helpful in determining whether natural or human-related factors are influencing the local genetic structure of green turtle rookeries. For example, if distance-related genetic structure tends to be a feature of populations occupying undeveloped beaches, but is absent in populations from highly developed areas, this would suggest that local genetic structure in green turtle rookeries is more strongly influenced by dramatic human activities than by the quality of environmental cues or other aspects of the natural ecology of the nesting beach.

\section{Acknowledgements}

This study was supported by grants from Sigma $\mathrm{Xi}$, the American Museum of Natural History, Wildlife Conservation International, and the Caribbean Conservation Corporation to T. Peare; and the National Science Foundation no. DEB-9322544 to P.G. Parker. We thank M. Bell, C. Campbell, R. Carthy, L. Ehrhart, E. Giuliano, L. Gonzales, M. Guevara, G. Holloway, N. Israel, S. Johnson, T. Lenihan, A. Leslie, R. Morse, E. Peare, R. Peare, A. Peterka, J. Rabenold, A. Rabenold and J. Winborne for help in the field, and T.J. Jones, K. Lundy, J. Rieder and T. Waite for help in the laboratory and with analyses. We also thank L. Kramer and D. Warmolts at the Columbus Zoo for their assistance, and two anonymous reviewers for their comments on this manuscript.

\section{References}

ALLARD, M. W., MIYAMOTO, M. M., BJORNDAL, K. A., BOLTEN, A. B. AND BOWEN, B. W. 1994. Support for natal homing in green turtles from mitochondrial DNA sequences. Copeia, 1994, 34-41. 
ANTLFINGER, A. E. 1981. The genetic basis of microdifferentiation in natural and experimental populations of Borrichia frutescens in relation to salinity. Evolution, 35, 1056-1069.

ANTONOVICS, J. AND BRADSHAW, A. D. 1970. Evolution in closely adjacent plant populations. VIII. Clinal patterns at a mine boundary. Heredity, 25, 349-362.

BARRowClough, G. F. AND COATS, S. L. 1985. The demography and population genetics of owls, with special reference to the conservation of the spotted owl (Strix occidentalis). In: Gutierrez, R. J. and Carey, A. B. (eds) Ecology and Management of the Spotted Owl in the Pacific Northwest, pp. 74-85. US Forest Service, Portland, OR.

BISHOP, J. A. 1981. A neo-Darwinian approach to resistance: examples from mammals. In: Bishop, J. A. and Cook, L. M. (eds) Genetic Consequences of Man-Made Change, pp. 37-51. Academic Press, London.

BISHOP, J. A. AND HARTLEY, D. J. 1976. The size and age structure of rural populations of Rattus norvegicus containing individuals resistant to the anticoagulant poison warfarin. J. Anim. Ecol., 45, 623-646.

BISHOP, J. A., HARTLEY, D. J. AND PARTRIDGE, G. G. 1977. The population dynamics of genetically determined resistance to warfarin in Rattus norvegicus from mid Wales. Heredity, 39, 389-398.

BJORNDAL, K. 1982. The consequences of herbivory for the life history pattern of the Caribbean green turtle, Chelonia mydas. In: Bjorndal, K. (ed.) Biology and Conservation of Sea Turtles, pp. 19-26. Smithsonian Institution Press, Washington, DC.

BOWEN, B. W., MEYLAN A. B., ROSS, J. P., LIMPUS, C. J., BALAZS, G. H. AND AVISE, J. C. 1992. Global population structure and natural history of the green turtle (Chelonia mydas) in terms of matriarchal phylogeny. Evolution, 46, 865-881.

BURKE, T. AND BRUFORD, M. W. 1987. DNA fingerprinting in birds. Nature, 327, 149-152.

CARr, A. 1967. So Excellente a Fishe. Natural History Press, New York.

CARr, A. 1980. Some problems of sea turtle ecology. Am. Zool. , 20, 489-498.

CARR, A. 1982. Notes on the behavioral ecology of sea turtles. In: Bjorndal, K. (ed.) Biology and Conservation of Sea Turtles, pp. 19-26. Smithsonian Institution Press, Washington, DC.

CARR, A. AND CARR, M. H. 1972. Site fixity in the Caribbean green turtle. Ecology, 53, 425-429.

CARR, A. AND HIRTH, H. 1962. The ecology and migrations of sea turtles, $\mathrm{V}$ : Comparative features of isolated green turtle colonies. Am. Mus. Novit., 2091, 1-42.

CARR, A. AND OGREN, L. 1960. The ecology and migrations of sea turtles, IV: The green turtle in the Caribbean Sea. Bull. Am. Mus. Nat. Hist., 121, 1-48.

CARR, A., CARR, M. H. AND MEYLAN, A. B. 1978. The ecology and migrations of sea turtles. 7. The west Caribbean green turtle colony. Bull. Am. Mus. Nat. Hist. , 162, 1-46.
CHAPMAN, R. W. 1989. Spatial and temporal variation of mitochondrial DNA haplotype frequencies in the striped bass (Morone saxatilis) 1982 year class. Copeia, 1989, 344-348.

DECKER, M. D., PARKER, P. G., MINCHELLA, D. J. AND RABENOLD, K. N. 1993 Monogamy in black vultures: genetic evidence from DNA fingerprinting. Behav. Ecol, , 4, 29-35.

EHRLICH, P. R. AND RAVEN P. H. 1969. Differentiation of populations. Science, 165, 1227-1232.

FRAZER, N. B. AND LADNER, R. C. 1986. A growth curve for green turtles (Chelonia mydas) in the U.S. Virgin Islands. Copeia, 1986, 798-802.

GeORges, M., LequarRe, A.-S., CASTElli, M., hanset, R. AND VASSART, G. 1988. DNA fingerprinting in domestic animals using four different minisatellite probes. Cytogenet. Cell Genet., 47, 127-131.

GILBERT, D. A., LEHMAN, N., O'BRIEN, S. J. AND WAYNE, R. K. 1990. Genetic fingerprinting reflects population differentiation in the California Channel Island fox. Nature, 344, 764-766.

JAIN, S. K. AND BRADSHAW, A. D. 1966. Evolutionary divergence among adjacent plant populations. I. The evidence and its theoretical analysis. Heredity, 20, 407-441.

JEFFREYS, A. J., WILSON, v. AND THEIN, S. L. 1985. Hypervariable 'minisatellite' regions in human DNA. Nature, 314, 67-73.

JOHNSON, s. 1994. Reproductive Ecology of the Florida Green Turtle (Chelonia mydas). M.Sc. Thesis, University of Florida.

KOCH, A. L., CARR, A. F. AND EHRENFELD, D. w. 1969. The problem of open-sea navigation: the migration of the green sea turtle to Ascension Island. J. Theor. Biol., 22, $163-179$.

Lohmann, K. J. 1992. How sea turtles navigate. Sci. Am., 266, 100-106.

LONGMIRE, J. L, LEWIS, A. W., BROWN, N. C., BUCKINGHAM, J. M., CLARK, L. M., JONES, M. D. ET $A L$. 1988. Isolation and molecular characterization of a highly polymorphic centromeric tandem repeat in the family Falconidae. Genomics, 2, 14-24.

LYNCH, M. 1990. The similarity index and DNA fingerprinting. Mol. Biol. Evol., 7, 478-484.

MANTEL, N. 1967. The detection of disease clustering and a generalized regression approach. Cancer Res., 27, 209-220.

MEYlAN, A. B., BOWEN, B. W. AND AVISE, J. C. 1990. A genetic test of the natal homing versus social facilitation models for green turtle migration. Science, 248, 724-727.

MORTIMER, J. A. 1982. Factors affecting beach selection by nesting sea turtles. In: Bjorndal, K. (ed.) Biology and Conservation of Sea Turtles, pp. 45-51. Smithsonian Institution Press, Washington, DC.

MORTIMER J. A. AND PORTIER, K. M. 1989. Reproductive homing and internesting behavior of the green turtle (Chelonia mydas) at Ascension Island, South Atlantic 
Ocean. Copeia, 1989, 962-977.

PARKER, P. G. AND WHITEMAN, H. 1993. Genetic diversity in fragmented populations of Clemmys guttata and Chrysemys picta marginata as shown by DNA fingerprinting. Copeia, 1993, 841-846.

PIPER, W. H. AND PARKER RABENOLD, P. 1992. Use of fragment-sharing estimates from DNA fingerprinting to determine relatedness in a tropical wren. Mol. Ecol., 1, $69-78$.

RABENOLD P. P., RABENOLD K. N., PIPER W. H., HAYDOCK J. H. AND ZACK S. W. 1990. Shared paternity revealed by genetic analysis in cooperatively breeding tropical wrens. Nature, 348, 538-540.

ROHLF, F. J. 1990. NTSYs-pc: Numerical Taxonomy and Multivariate Analysis System. Version 1.60. Applied Biostatistics, Setauket, New York.

ROHLF, F. J. AND SCHNELL, G. D. 1971. An investigation of the isolation-by-distance model. Am. Nat., 105, 245-324.

SCHNELL, G. D., WATT, D. J. AND DOUGLAS, M. E. 1985. Statistical comparison of proximity matrices: applications in animal behaviour. Anim. Behav, 33, 239-253.

SELANDER, R. K. 1970. Behavior and genetic variation in natural populations. Am. Zool, 10, 53-66.

SNAYDON, R. W. AND DAVIES, M. S. 1972. Rapid population differentiation in a mosaic environment. II. Morphological variation in Anthoxanthum odoratum. Evolution, 26, 390-405.
SOKAL, R. R. AND WARTENBERG, D. E. 1983. A test of spatial autocorrelation analysis using an isolationby-distance model. Genetics, 105, 219-237.

SOUTHERN, E. M. 1975. Detection of specific sequences among DNA fragments separated by gel electrophoresis. J. Mol. Biol., 98, 503-517.

TRIGGS, S. J., WILLIAMS, M. J., MARSHALL, S. J. AND CHAMBERS, G. K. 1992. Genetic structure of blue duck (Hymenolaimus malcorhynchos) populations revealed by DNA fingerprinting. Auk, 109, 80-89.

WEIDER, L. J. 1985. Spatial and temporal genetic heterogeneity in a natural Daphnia population. J. Plankton Res., 7, 101-123.

WHite, M. M. AND SVENDSEN, G. E. 1992. Spatial-genetic structure in the easten chipmunk, Tamias striatus. J. Mammal., 73, 619-624.

WITHERINGTON, B. E. 1992. Behavioral responses of nesting sea turtles to artificial lighting. Herpetologica, 48, 31-39.

WORTH, D. F. AND SMiTH, J. B. 1976. Marine turtle nesting on Hutchinson Island, Florida, in 1973. Florida Mar. Res. Publ., 18, 1-17.

WRIGHT, s. 1943a. Isolation by distance. Genetics, 28, $114-138$.

WRIGHT, S. 1943b. An analysis of local variability of flower color in Linanthus parryae. Genetics, 28, 139-156.

WRIGHT, s. 1951. The genetical structure of populations. Ann. Eugen., 15, 323-354. 